\title{
Application of Multiple Intelligence Theory in College English Teaching
}

\author{
Jianlei Zhou \\ Baoding Technical College of Electric Power, 071000
}

Keywords: multiple intelligence theory; college English; application experience; personalization

\begin{abstract}
This paper mainly discusses the application of multiple intelligence theory in college English teaching, and demonstrates the feasibility of the multiple intelligence theory in conjunction with related specific teaching activities to adapt to the development of college English teaching. Through practice, it can be concluded that multiple intelligence theory can not only stimulate students' interest in learning, but also establish students' confidence in learning English, increase teacher-student interaction, and create a relaxed learning environment.
\end{abstract}

\section{Introduction}

The theory of multiple intelligences comes from abroad, mainly based on research psychology. It believes that human individuals have at least eight kinds of intelligence, such as interpersonal intelligence, language intelligence, logical thinking intelligence, natural cognition, audiovisual language intelligence, and limbs. Sports intelligence and so on. Because individuals have differences, each person has different perceptions of things and problems, which forms a smart distinction. Therefore, in the process of college English teaching, multiple intelligences can be infiltrated to explore students' learning potentials and talents and inspire students' innovative ability.

\section{Specific Analysis of Application of Multiple Intelligence Theory in College English Education}

In the following, we will take a college as an example to discuss the application of multiple intelligence theory about English teaching and analyze its effects . After entering the new students, they will implement " graded " and " sub-curricular " methods to adjust English teaching . First of all, students need to conduct an English test, and then divided students into groups according to their grades. They can be divided into groups I , II , and III . Students in group III are weak in English learning, most of them are student majors in art and music or students who majored in science but has weak basis of English. If the total number of students are 300 , a questionnaire survey of English learning will be conducted in the same class and other poorly-based classes after one semester. The contents of the questionnaire survey to include : major to score, English scores , purpose of learning English, and whether there are difficulties, time for learning English every day, and an ideal English classes as English learning. A total of 500 questionnaires were distributed and 480 actually valid questionnaires. According to the survey results , 45.7\% of the students were very difficult to learn English, and $81 \%$ of the students learned English every day . In less than two hours , 54.8\% of the students hope that teachers in English classes should organize more activities and interact more with teachers in English .

From the investigation results, we can see that in order to stimulate students ' interest in learning English and to take into the learning foundation of different students account, the multiple intelligence theory can be used to adjust English teaching. In the poorly-founded English classes , art students account for a quarter. Before starting classes, they can be divided into several groups . Each of the four students are divided into a group and a group leader is selected to take charge of group activities . For example, in the New Horizons College English Reading and Writing Course (2nd Edition ) published by the Foreign Language Teaching and Research Press, the theme of the 
first unit in the textbook is Learning a foreign language. There are many drawbacks to the previous courses. Most of them are Teachers speak in class and lack interaction with students . Therefore , multiple intelligence theory can be applied to allow each student to speak English and to select a prominent student through voting. Other groups can participate in singing or drawing to show English together. Students can tell interesting things that happened to their English teachers and presented them in the form of drawing by team members. Finally, it summarizes the key vocabulary and grammar skills of the lesson by combining the content of the text. This also deepens students ' interest in learning, improves their oral English ability, and promotes the exchanges of teachers and students .

In terms of training students ' language intelligence, teachers can set up reading masterpieces , discussion topics, and role-playing methods in the group during English literacy classes . When learning each lesson, the teacher can play some video voices and show them in front of the students in a visual and audio language. For example, when it comes to how to leave a good impression of the other party, the teacher can give students some occasion etiquette from other countries . After the broadcast, the team representative will dictate to English. The teacher will explain some important words and grammar in the video. This will not allow students to exercise their spoken ability, but also allows students to understand the culture of other countries. In the poor science and engineering base, the teacher gave each group an English short essay to allow the group members to read aloud, on the one hand, to exercise the students ' speaking ability, and on the other hand to train their listening ability .

In terms of physical intelligence, when it comes to the chapter "Test of true love", group members can be read in roles, narrators, soldiers, and women. After reading the texts, they will give lectures in the class and make selections. Students can also add some ideas to arrange and process. Through such a class experience, students have the ability to think and use, so that they can realize their potential and go further on the way to learning English.

In terms of logical thinking, science classes with a poor English foundation are the main ones. In English teaching courses, inference or speculative activities can be set up. For example, in the reading session, you can send a card to each group. There is a title on the card. According to the topic, the content related to the topic is drawn. Then the other team can guess. This not only achieves visual intelligence, but also Learning English as a logical thinking ability also learns English. Even without guessing correctly, this deepens students' memory of English vocabulary.

\section{Role of Multiple Intelligence Theory in College English Teaching}

\subsection{Team-style Language Training Improves Students' Self-Confidence}

Through English training in the form of sub-groups, students with introverted and poor communication can be involved, and students can learn from each other. The four-person group mode can form a good learning environment. Good English students can guide other students. Poorly-based students can also learn a lot in them. Everyone in the group helps each other and communicates and shares. As a teacher, you can comment on your classmates' learning process and comprehensively and fairly evaluate students' language skills.

\subsection{Create Relaxed and Active Classroom Atmosphere and Establish Harmonious Teacher-student Relationship}

According to the questionnaire survey, most students hope that the classroom atmosphere is more relaxed and active, especially for language-related disciplines, learning environment is particularly important. When designing classroom teaching content, English teachers should consider the differences of students and let each student participate in the classroom teaching activities. While alleviating the pressure on teachers, the English teachers also increase their interest in learning. For 
example, each group separately describes a crime scene. The students will have their own opinions. Each person will speak with their own experiences. The teacher's commentary guides the students to complete the classroom tasks well. Each group is selected and the outstanding group is summary and share. A good and relaxed classroom atmosphere can not only improve students' English learning ability, but also promote a more harmonious relationship between students and students.

\subsection{Diversity in Classroom Activities to Meet the Diverse Needs of Students}

Students with poor English basics, especially students who majors in art and music, are more outgoing and imaginative than other professional students. Because they need to spend a lot of energy on professional courses, their general English foundation is poor, but they also hope to be able to improve English performance, and the traditional teaching model to some extent hindered their development . Therefore, the application of multiple intelligence theory about the English teaching process, combined with the specific circumstances of the students to design English teaching activities, so that they participate in , to eliminate their anxiety in learning English . Studnents who majors in art and music are tend to be outgoing and good at expressing themselves . As English teachers in colleges and universities should be good at guiding them , designing English scenes and dialogue scenes related to their majors, such as classes for learning music, English singing competitions can be divided into groups ; classes as performing classes, it can be selected at home and abroad famous film and television clips for on-site role-playing .

\section{Conclusion}

Under the guidance of multiple intelligence theory, college English teachers can design classroom teaching content from different perspectives and use grouping mode to teach English so that each student can participate. Based on this, this article first analyzes the specific application of the multiple intelligence theory in college English education with reference to the specific teaching design content, and then puts forward the role of multiple intelligence theory in college English teaching, such as improving students' self-confidence; establishing a harmonious teacher-student relationship; to meet the different needs of students, the final hope that through the analysis of this article can provide a reference for college English teaching.

\section{References}

[1] Song Qinghua. Application of multiple intelligence theory in high school English teaching [J]. Middle school English 2017 (42)

[2] Liu Min. Practice and Thinking of English Simultaneous Typing Classroom Teaching and Evaluation System Based on Multiple Intelligence Theory[J]. Crazy English (Theory) 2017(03)

[3] Gao Ling. The current situation of multiple intelligences theory in English teaching in higher vocational education under the double certificate system[J]. Times Education 2015(18)

[4] $\mathrm{Xu}$ Wentao, Peng Guangzheng. Investigation and Analysis of College Students' English Multiple Intelligences[J].兰州 Journal of School of Education 2015(10)

[5] Li Qin.Discussion on junior high school English difference teaching strategies from the perspective of multiple intelligence theory[J]. Campus English 2015(25) 